\title{
Are firms exporting to China and India different from other exporters?
}

\author{
Giorgio Barba Navaretti, Matteo Bugamelli, Riccardo Cristadoro and \\ Daniela Maggioni
}

\begin{abstract}
This chapter asks if and why advanced countries differ in their ability to export to China and India. To this end we exploit a newly collected, comparable cross-country dataset (EFIGE) obtained from a survey of 15,000 manufacturing firms in Austria, France, Germany, Hungary, Italy, Spain and the United Kingdom. The EFIGE dataset contains detailed information on firms' international activities as well as firms' characteristics like size and productivity, governance and management structure, workforce, innovation and research activity. We study both the extensive and intensive margins of exports and identify the firm characteristics that are positively or negatively correlated with exporting activity tout court and with exporting to China and India conditional on being an exporter. We confirm previous rich evidence and show that larger, more productive, and more innovative firms are more likely to become exporters and export more. We also provide some new evidence on the role of governance and management: while there does not seem to be a strong negative effect of family ownership, we find that a higher percentage of family management reduces a firm's export propensity and export volumes. When we turn to exports to China and India, we find that firms exporting there must be on average larger, more productive and innovative than firms exporting elsewhere.
\end{abstract}

\section{Introduction}

In advanced countries, the economic and political debate on the impact of globalization is dominated by the negative effects, mostly in terms of employment, coming from the rapid rise of emerging economies, like China and India, as fierce competitors on world markets of goods and services. The other side of the coin has so far received less attention: China and India are also exceptionally large and very dynamic destination markets that benefit advanced countries' exports and growth.

In the last two decades the weight of China in the globalised world has remarkably risen and China has become one of the most important players in international trade. This process of integration has accelerated with its entry into the WTO in 2001. WTO membership has implied the lowering of import tariffs and the authorisation for foreign firms to sell directly in the Chinese market. These policy measures have further opened the door to foreign firms. China is not only a supplier of low-cost inputs for developed countries but has become an expanding market, offering profitable business opportunities. 
Exports to China have been growing for all developed countries. Because of proximity, this rise has been especially fast in Japan and other industrialised Asian economies. Trends are on the rise in all countries, although some, and especially Germany, have been especially successful in strengthening their position in Asian markets. Others are lagging behind. China's share in total Italian exports is lower than for the EU15 average. In this chapter we study the causes of these differences, using the new EFIGE data set, which includes information on firms' international activities for 7 European economies (Austria, France, Germany, Great Britain, Hungary, Italy and Spain, see Barba Navaretti et al., 2011).

It is of course a well known fact that the distributions of firms' characteristics are extremely heterogeneous within countries and industries. Also a large body of theoretical and empirical literature (Helpman et al., 2004, Eaton et al., 2004) has highlighted how these characteristics are likely to affect export performance.

The key discriminatory features are size and productivity, given the high fixed costs of carrying out international activities. The first step of our analysis, therefore, is understanding how far the distribution of these features of European firms affect i) the extensive and intensive margins of exports and ii) the intensive and extensive margins of exports to China and India. ${ }^{1}$ Exporting to distant emerging markets involves higher costs and risks than supplying nearby European customers. We expect therefore that only the best performing firms among the exporters manage to access faraway destinations.

We find in fact that basic firm characteristics like size and productivity, carry the brunt of the explanatory power, more than country and industry features. In a sense, we are giving support to a kind of monotonicity argument: small and lowproductivity firms do not export, firms with average size and productivity sell their products to foreign and, presumably, close markets, while firms that are even larger and more productive can export to distant and difficult markets (see Melitz, 2003).

As a second step, we try to delve into the black box of firms' characteristics. Productivity and size are of course second order outcomes of strategic choices like governance, technology, composition of factors of production etc. And also, for given productivity and size these other features may provide independent explanatory power for firms success in foreign markets. Governance is likely to play a very relevant role. A central factor is of course family ownership. Its influence on overall performance and strategic choices, like entering export markets, has been extensively analysed in the literature. Family ownership is generally perceived as a hindering factor because of risk aversion in decision making (Barba Navaretti et al., 2008), dynastic management (Caselli and Gennaioli, 2003; Bennedsen et al., 2007), dilution of capital and control (Ellul et al., 2010), reluctance to decentralise decision making and so forth. Given the pervasiveness of family control in Euro-

\footnotetext{
${ }^{1}$ The Efige data set does not provide information on exports to the two countries separately.
} 
pean firms $\left(86\right.$ per cent $\left.{ }^{2}\right)$, we regard it as a central aspect of our investigation to dissect its influence on firms exporting performance. Of course, the impact of ownership also depends on governance and management structure: managers can still be independent, can be non family member professionals, the decision process can be decentralized even with family owners, managers with expertise in international business can be hired. We therefore try to establish whether and to what extent these features influence export decisions.

We find that family ownership does indeed lower firms' export propensity, but that the ownership effect is strictly related to how far the family relinquishes decisional power to external managers. In fact, it is the presence of family members in executive management that drives the negative relationship between family ownership and export performance. Once we control for this factor, family ownership per se is no longer significant. Export propensity is also lower if executives have no previous foreign experience and when strategic decision making is not decentralised. These features are also linked in a similar way to the further step of exporting to faraway emerging markets.

The reminder of the chapter is organised as follows. The next section presents the data and a set of key stylized facts. Section 3 reports the basic estimations of the extensive and intensive margins of European exports, both in general and towards China and India. In this basic estimation we only include standard firm level characteristics like size and productivity. Section 4 looks at the impact of type of ownership and governance. Section 5 concludes.

\section{Data and descriptive statistics}

Figure A1 shows that exports to China have grown for all developed countries. Japan and other industrialised Asian countries profited the most form the expansion of the Chinese market due to their proximity. Figure A2 focuses on European countries included in the dataset: Austria, France, Germany, Hungary, Italy and UK and Italy. The trends are quite similar, but while in 1990 the export share to China was comparable among European countries, in 2008 the share for EU countries (in particular France and Germany) became on average higher than the Italian one.

Which are the determinants of the firms' success in exports and are there some heterogeneous effects explaining export to faraway countries compared to export to neighboring countries? We will try to answer these questions making use of the Efige dataset, a firm level database collected within the project "Efige - European

\footnotetext{
2 According to the "wide" definition of family ownership considered in this paper, which includes also firms where the main shareholder has more than $30 \%$ of the capital. Using the narrower definition (firms that declared to have a "family ownership") the share in our sample reduces to $74 \%$.
} 
Firms in a Global Economy: internal policies for external competitiveness". Data concern seven European Union countries: Austria, Germany, France, Hungary, Italy, Spain and UK. The sample distribution by country is shown in Table A1. The survey questionnaire contains both qualitative and quantitative information covering different areas: the ownership and management structure of the firm, its employment composition, investment and innovation activity, its internationalization strategies and the financial structure. Survey data have been matched with balance sheet information drawn from the Amadeus database, managed by Bureau van Dyck, to retrieve an indicator of labour productivity.

The survey has been carried out once in 2010. Only balance sheet data have a panel structure. The results reported in our analysis are therefore essentially descriptive.

For the aim of the present work we mainly exploit information concerning the firm international activity, ownership and management structure. Our focus is both on the export activity in general, regardless of the destination country, and on the exports to China and India. ${ }^{3}$ The survey questionnaire allows us to split destination markets in 8 groups: European Union (EU-15), other European Union countries, other European Countries (outside EU), China and India, other Asian countries, USA and Canada, Central and South America, other countries. ${ }^{4}$

Figure A3 provides a bird's eye view of the distribution of European exporters by destination country. The great part of them sells to close markets (EU15), while only a small number of firms successfully reaches faraway ones.

This could be due both to their cultural distance (consumers' tastes and preferences in China and India may be different from the ones in western countries and this may require the need to adapt products for exports) and to the fact that experience of European firms in these countries is still scarce and time is needed to reap the new business opportunities offered by these countries.

The share of Italian firms exporting to China and India $(17.7 \%)$ on the population of exporters is much lower than in Germany or France (27.3 and 22.2\%, respectively); this is in contrast with findings on the share of exporters to extraEuropean markets excluding China and India (see table A3). Here the share of Italian firms is indeed higher than for other European countries, as if China and India had high entry costs compared to other distant markets, USA and Canada and these costs were especially binding for Italian exporters. On the other hand German exporters are more likely to penetrate difficult markets, that are geographically and culturally distant. These differences across countries could be explained by their different industrial structure in terms of firms' size, sectoral distributions, innovative capacity and productivity. Thus, the advantage of Germany in emerging countries could be related to its sectoral specialization or, more likely, to the

\footnotetext{
${ }^{3}$ The questionnaire does not allow to distinguish exporters to China from exporters to India. In the text we sometimes refer to these two countries as emergent countries.

${ }^{4}$ The geographical destination of exports is recorded only for 2008. Thus, when we analyze the destination-specific experience of exporters we focus only on that year.
} 
great role (weight) that medium and large firms have in German manufacturing (see Barba Navaretti et al, 2010).

Table A4 shows that exporters are on average larger (measuring size in terms of employment) and more productive (measuring productivity by output per worker) than non exporters, confirming a well known result. However, significant gaps also exist between exporters to emerging countries and exporters to other countries. Considering only the firms in our sample that do export, we observe that those operating in China and India are on average (and significantly) bigger than other exporters. On the contrary, we do not detect any significant difference when comparing simple productivity measures. Quite interestingly differences are not confined to the firms structural or economic characteristics, also ownership and management practices make a significant difference. Reaching faraway markets is more likely when a firm belongs to a group, it is not a "family-enterprise" with a CEO who is a member of the owning family and when it promotes best management practices by rewarding managers according to performance and by adopting a management structure with decentralised responsibility. This is true not only when we compare exporters to non exporters, but also, within the group of "international" firms, when we single out those that have entered faraway markets.

\section{The extensive and intensive margin of trade: base regressions}

In the previous section we have highlighted the main characteristics of exporting firms. Now we move to a more general and systematic approach and perform a regression analysis of the extensive and intensive margins of trade on country, sector and firm characteristics. In this way, we can assess the relative importance of the different factors and the magnitude of their impact on exports.

The main objective of the paper is to unveil (and measure the impact of) the distinctive features of firms that succeed in exporting to China and India. Before turning to that, though, it is useful to set the stage by looking at the characteristics of exporters irrespectively of the destination markets.

The most recent contributions to the international trade literature with heterogeneous firms provide wide support, both theoretical (Bernard, Jensen, Eaton and Kortum, 2003; Melitz, 2003; Melitz and Ottaviano, 2008) and empirical (Bernard and Jensen, 1995, 1999, 2004a, 2004b, ISGEP, 2008), ${ }^{5}$ to the idea that exporting

\footnotetext{
${ }^{5}$ The project sought to study the relationship between exports and productivity by reducing methodological and statistical differences. Some 40 researchers took part, conducting analyses of firm-level data from 14 countries (Austria, Belgium, Chile, China, Colombia, Denmark, France, Germany, Ireland, Italy, Slovenia, Spain, Sweden and the United Kingdom). Davide Castellani of the University of Perugia, Francesco Serti and Chiara Tomasi of the Scuola Superiore Sant'Anna in Pisa participated for Italy.
} 
firms are more productive, larger, more profitable and innovative than average. ${ }^{6}$ Moreover, when restricting the analysis to the exporting firms, it turns out that there are further important heterogeneities; in particular, in all main European countries, there is a large mass of small exporters and very few large firms that make a great part of a country's exports ("superstars", see Mayer and Ottaviano, 2007; Barba Navaretti et al., 2011).

Why are exporting firms "better" than average? Here the empirical trade literature has focused on two hypotheses: that exporting firms are ex ante "above average" ("self-selection" hypothesis) or that their higher productivity is instead the result of the export activity itself ("learning-by-exporting" hypothesis).

According to the self-selection idea, it is "harder" to export than to sell on domestic markets and so only the best firms are able to do it. The difficulty of exporting is ascribed to the presence of fixed costs specific to export activity, such as transportation, distribution and marketing costs or the costs of hiring qualified personnel to manage relations with international customers. The hypothesis of fixed export costs, which was first put forward by Baldwin (1988 and 1989), Baldwin and Krugman (1989), Dixit (1989) and Krugman (1989) and underlies theoretical models with heterogeneous firms à la Melitz, implicitly presupposes a barrier to entry in foreign markets that the less productive firms are unable to overcome. Starting with the work of Roberts and Tybout (1997), numerous empirical studies have corroborated this hypothesis; ${ }^{7}$ for Italy, the presence of fixed export costs has been demonstrated by Castellani (2002) and by Bugamelli and Infante (2003).

Learning-by-exporting can derive from the fact that the greater competitive pressure to which exporting firms are exposed drives them to achieve efficiency gains, or else from the possibility for exporters to learn better technologies from foreign competitors or ideas for the renewal and improvement of their product range from foreign customers (Clerides, Lach and Tybout, 1998; Bernard and Wagner, 1997).

Since the mid-1990s, in part with the growing availability of firm-level data, a stream of works has tested these two hypotheses. Reviewing 45 studies on 33 countries published between 1995 and 2006, Wagner (2007) concludes that exporting firms are definitely more productive than average owing to a self-selection effect, whereas entering foreign markets does not necessarily lead to an increase in efficiency at firm level. These results have been confirmed by an international comparative research project launched by the International Study Group on Exports and Productivity (see ISGEP, 2008).

In Table A5 we run a probit regression of an exporter dummy variable which is equal to 1 if a firm exported a positive amount in 2008 and 0 otherwise. This is the

\footnotetext{
${ }^{6}$ In the case of Italy, these results have been confirmed by various authors (Ferragina and Quintieri, 2000; Sterlacchini, 2001; Basile, 2001; Castellani, 2002; Bugamelli and Infante, 2003; Serti and Tomasi, 2008).

${ }^{7}$ See Bernard and Wagner (1997) for Germany, Bernard and Jensen (2004b) for the United States, Campa (2004) for Spain, Poddar (2004) for India, and Girma, Greenaway and Kneller (2004) for the United Kingdom.
} 
so-called extensive margin of exports. In a first specification (column 1) we include only country dummies. With respect to Germany (the excluded country), the propensity to export is higher in Austria, Italy, Hungary and UK. France and Spain are in line with Germany. In column 2 we add sector dummies (2 digits of the Nace 2 rev.1 classification): apart from small changes in the coefficients of the country dummies, the sectoral dummies (not reported) point to significant differences across sectors. The share of firms engaged in export activity is lowest in the food industry, followed by traditional, low-tech activities. Chemical and mechanical firms are most likely to export.

Things interestingly change when we start adding firms' characteristics (columns 3-7). Overall, we confirm the received view from the existing empirical literature: size, productivity, the skill level of the workforce ${ }^{8}$ and propensity to innovate are positively correlated with the export status. The inclusion of firm-level controls in general reduces the relevance or the size of the country dummies.

In Table A6 we show the results for the intensive margin of exports, measured by the log of exported turnover. In terms of firm characteristics, we find again a very relevant and positive impact of firm size and productivity; even after controlling for those two characteristics the skill composition of the workforce has a significant, though small, positive effect on exports. The country dummies depict a slightly different story than in the case of the extensive margin. In column 1, where we control neither for sector nor for firms' characteristics, we see that France, Italy, Spain and Hungary record a lower level of exports than Germany. The positive gap between Germany on one side and Italy on the other appears to be due to firm size (column 3): once we control for firm's size, the coefficient of Italy's dummy becomes positive. The gap with France and Hungary is due to firm productivity (column 4). In the richest specification (column 7), Italy and Hungary have a positive and statistically significant coefficient of the country dummy, while Spain has still it strongly negative.

To sum up, firm characteristics - size, productivity, innovation, skills of the workforce - are the primary determinants of export performance and dominate country effects. Firm characteristics almost always affect the probability of engaging in exporting and the export level in the same direction: larger and more productive firms are both more likely to export and tend to export a larger amount of their production.

We now move to the analysis of exports to China and India and run regressions conditional on exporting: this restriction to a sample that includes only the exporters allows us to identify country, sector and firm characteristics that raise the probability that an already exporting firm sells its products also in China and India.

\footnotetext{
${ }^{8}$ In all the regressions we only report results for one measure of skills, the share of graduate employees. Results are not affected if we use the share of managers and white collars on total employment instead.
} 
The results for the extensive margin are reported in Table A7. As shown in column 1, where no controls other than country dummies are included, all countries, except UK, are performing worse than Germany: the gap appears to be larger for Hungarian and Spanish firms and smaller for French ones. Unfavourable sectoral specialization explains part of the countries' gap with respect to Germany: the gap is indeed reduced once we control for sectors (column 2). Firm's characteristics are in general highly significant with the sole exception of capital intensity, that does not affect the probability that a firm that is already an exporter will sell its products also in China and India, and of labour productivity that in some regressions is not significant. These results are far from obvious: even among exporters, that are already larger, more productive and innovative than average, size, productivity, innovation and the education level of a firm's labour force are relevant competitive factors to reach distant and large markets like China and India.

In a sense, we are giving support to a kind of monotonic relation: small and low-productivity firms do not export, firms with average size and productivity sell their products to foreign and, most often, close markets, while to reach distant and difficult markets firms must be even larger and more productive.

The effects of size and skill on the probability to export to China and India are quantitatively comparable to those that they have on being an exporter (see Table A5). Labour productivity, on the other hand, has a feebler and sometimes statistically negligible effect on the likelihood of serving far away markets, once a firm is already selling abroad its products. This can suggest that exporting to China and India entails higher fixed costs that can be better faced exploiting greater economies of scale and requires additional skills and innovation activity, while the level of productivity per se is not relevant. Care must be exerted, though, since the collinearity among workers' skills and productivity is arguably very high.

The regressions on the intensive margin for China and India (Table A8) confirm the monotonic relation suggested by the probit models. In a parallel with the results of Table A6, size, productivity and the skill composition of the workforce record significantly positive coefficients. On the other hand, the innovation dummy is no longer significant. Two explanations can be offered, not necessarily as alternatives. The very nature of the "innovation regressor", that is a dummy assuming value 1 if the firm engaged in some innovation activity makes it ill suited to measure the intensity of this activity so that we might well find that it influences the probability of exporting to China and India, but not the amount exported. Furthermore, among the group of exporters, the number of innovative firms is very large, surpassing 4 fifths of the sample, hence the actual power of the test of significance of the coefficient might indeed be quite low. ${ }^{9}$ Turning to coun-

\footnotetext{
${ }^{9}$ This might also explain why innovation significantly influences not only the probability of being an exporter but also the amount exported in the previous regressions, where the population is given by all firms, including non exporters.
} 
try dummies, the gap of Italian firms with respect to German competitors is due to the unfavourable size structure, that of French firms to a lower productivity.

\section{Controlling for type of ownership and management practices}

In this section we focus on the role of ownership and management practices: do they influence the ability to export, once all the other firm's characteristics have been taken into account as seen above? The issue is particularly important for our sample. As shown in table A9 in all European countries the large majority of firms is family-owned.

Many papers have analysed theoretically and empirically how family ownership affects performance in general (Caselli and Gennaioli, 2003, Burkart, Panunzi and Shleifer, 2003, Perez-Gonzalez, 2006, Sraer and Thesmar, 2006, Favero et al 2007, Bertrand and Schoar, 2006), even after controlling for size and productivity. Fewer have looked at the effects on export activities. Barba Navaretti, Faini and Tucci (2008), controlling for management and other firm characteristics, show that Italian family firms export a lower share of their output to extra European markets than non family firms. Their paper focuses on risk aversion: as a large share of the assets of the family are concentrated in the business, limited opportunities for risk diversification constrain the undertaking of risky activities like exporting to faraway markets. ${ }^{10}$

Naturally there are many examples of family firms which are very successful internationalized firms. These firms essentially manage to overcome the constraints of a restricted ownership, by hiring competent independent managers, possibly with wide international experience, by decentralizing decision making and by introducing advanced governance practices. Marin and Verdier (2003 and 2006) show how export performance is related to the degree of decentralisation of the governance of the firm. Mion and Opromolla (2011) find that hiring managers with previous export experiences increases the chances the firm will export. Finally, Bloom and Van Reenen (2007) highlights how management practices vary across Europe and how these affect firm level performance.

Consequently in this section we combine ownership information with characteristics of management to assess their joint effect on exporting in general and specifically on exporting to China and India.

The first set of regression compares exporters' characteristics to those of the whole population of firms. Looking first at the extensive margin, we progressively add to the set of regressors used in Table A5, variables concerning family ownership and management practices. Being a "family firm", according to the wider concept of family ownership discussed in appendix A ("family_wide" variable),

\footnotetext{
${ }^{10}$ As mentioned before, other reasons why family ownership may hinder exports include limited
} delegation in decision making, dynastic management, aversion to a dilution of assets and control. 
negatively affects the probability of being an exporter (see Table A10). But this is true only as long as we do not control for the characteristics of the management. When we distinguish firms according to the importance of family members in their management ("fam_exec" variable), family ownership is no longer significant, while if managers are selected within the family the probability that a firm sells products in foreign markets is significantly lower. This is a first insight into understanding that family ownership per se is not a critical factor for the international performance of firms. What really matters is how far shareholders are able to delegate managerial power outside the family boundaries. Of course there is a problem of endogeneity in this variable as well as in several others used to explain internationalisation patterns. Family firms may tap external managerial resources once they decide to enter foreign markets. Still this result tells us that whatever the causal links, using external managers is an important condition for successfully exporting.

That delegating power is important also emerges from the variable measuring the degree of centralization in the decision processes: firms with a highly centralized management structure, where there is little handing over of decisions and entrustment, are less likely to compete in foreign markets. One would expect this variable to be highly correlated to the presence of external managers in family firms, which by definition implies a concentration of decision making per se. The fact that this variable maintains explanatory power anyhow is of further support of the view that managerial practices are an essential factor for running global businesses. Delegation of power remains significant even after controlling for sector's characteristics. The latter control is crucial, since one might expect that the degree of trust and hence the amount of delegation within a firm depends, among other things, on the nature of competition within a given sector: where blueprints, knowhow and strategic decision are a key factor in firms' success, the risks linked to sharing sensitive information might limit the amount of optimal delegation. ${ }^{11}$ Not surprisingly, the presence of managers with foreign experience is also positively related to the probability of exporting. As for non-family mangers we cannot establish the direction of the causal link here, but still the positive sign of the correlation has important analytical value anyhow.

Finally, the sign (and size) of coefficients of the other standard firm-specific variables (size, productivity, innovation and skills) is not heavily affected by the introduction of the new regressors.

So far the evidence confirms that ownership and management characteristics play a significant role in explaining a firm's success as an exporter, even after we control for other important sources of firms' heterogeneity. What can one say of these variables when we compare exporters to China and India with other exporters?

\footnotetext{
${ }^{11}$ However the relationship between management centralization and export probability is a weak
} one, since the introduction of the variable measuring productivity wipes out its effect. 
Focusing on the probability of exporting to China and India (conditional on being an exporter) Table A11 shows that while family ownership is never significant, family managers still exert a negative effect. Belonging to a group is a contributing factor to exporting in faraway markets, while it was non significant in general. ${ }^{12}$ The foreign experience of managers is significantly enhancing the likelihood of exporting to China and India, while the degree of centralization in management is not significant. The latter result might be due to the fact that being an exporter already requires a certain level of delegation and any further handing over of decisional power does not translate in higher chances of exporting to China and India. Or that here decentralisation of decision making and the presence of non-family managers are highly correlated, in fact also this latter variable loses significance in the last regression. So in all, these results show that variables pertaining to the organisation of the firm matter for the further step of exporting to more difficult and distant markets.

Considering now - among the group of exporters - factors affecting the amount of merchandise sold on foreign markets (intensive margin), we find broadly speaking a confirmation of the results for the intensive margin of exports (see Table A12). Family ownership has a significant negative effect on the quantity of exports only as long as we do not control for management characteristics. Once we introduce the fam_exec variable only this has a significant (and negative) effect. Conversely, having a centralised governance no longer hinders sales in foreign markets. The quantity exported tend to be larger for firms belonging to a group and whenever managers of the firm have previous foreign experience. This result might support the hypothesis that the foreign experience of the managers positively influences the probability that a given firm exports, as it helps achieving larger sales and exploiting economies of scales to overcome the fixed cost of market entry.

Similarly, if we consider the intensive margin of exports to China and India, the quantity exported to faraway markets increases for firms within a group and in the presence of managers with foreign experience, thus confirming results found considering the intensive margin determinants for general exporters (Table A13). Family ownership is significant only when there is no control for family members in the management, in which case the usual conclusion holds. Again, centralization of the management has no effect.

Overall the evidence points to a very significant (and negative) role of the family presence in the management of the firms, and not so much of family ownership per se, not only for exporters in general but also when we compare them with firms that sell their products in China and India. Other factors that - conversely influence positively export performance in general and the ability to penetrate faraway markets in particular, are the international experience of the managers and being part of a group.

${ }^{12}$ That is in the probit regressions characterizing exporters versus non exporters. 


\section{Conclusion}

The importance of firm level characteristics for the export performance is not a new fact. A large strand of literature has documented the role of firms' size, productivity, skill composition and innovation as significant determinants of their international status. There exist additional costs of selling goods in foreign markets, such as transportation expenses and marketing costs, that represent an entry barrier. As a consequence, only large, efficient and innovative firms are able to cope with these costs and survive in the more competitive international market (Roberts and Tybout, 1995; Melitz, 2003). Our contribution to this literature is to investigate the role of the ownership and management structure of firms.

We ask whether ownership matters for internationalization, which management practices help firms to go international, and if their impact may be heterogeneous according to the destination country the firm wants to reach, in particular for emerging markets. A simple descriptive analysis reveals some facts that are in line with previous empirical studies. Family firms or family-managed firms have been showed to be less dynamic, less productive and more risk-adverse than other firms (Caselli and Gennaioli, 2003, Burkart, Panunzi and Shleifer, 2003, PerezGonzalez, 2006 and Barba Navaretti, Faini and Tucci, 2008,). Our evidence points out that what actually matters is not family ownership per se, but the degree of involvement of the family in the management of the firm. Exporters are less likely to be family-dominated than non-exporters, and among exporters firms selling to China and India are still less likely to be controlled by the family owner. The decentralization of decision-making and the foreign experience of managers also have significant positive influence on the probability of entering and on the ability to expand the activity in foreign markets. Exporters and, among them, exporters to China and India make use of decentralization strategies and their executives are more likely to have worked abroad. It is worth to notice that the differences between exporters to China and India and other exporters are at least as large as the ones between exporters and not exporters. Thus, not only exporters represent a peculiar group of firms, but firms entering emergent countries represent a still more peculiar sub-group. 


\section{References}

Baldwin, Richard E. (1988). Factor Market Barriers are Trade Barriers: Gains from Trade in 1992. NBER Working Paper Series, w2656. Available at SSRN: http://ssrn.com/abstract $=439582$

Baldwin, Richard E. (1989). Sunk-Cost Hysteresis. NBER Working Paper Series, w2911. Available at SSRN: http://ssrn.com/abstract $=459421$

Baldwin, Richard E. and P. Krugman (1989). Persistent Trade Effects of Large Exchange Rate Shocks. Quarterly Journal of Economics CIV, pp. 635-654.

Barba Navaretti G., M. Bugamelli, F. Schivardi, C. Altomonte, D. Horgos \& D. Maggioni (2011). The Global Operations of European Firms. Bruegel Blueprint Series, volume XII.

Barba Navaretti, Giorgio, Faini, Riccardo and Tucci, Alessandra (2008). Does Family Control Affect Trade Performance? Evidence for Italian Firms. Centro Studi Luca d'Agliano Development Studies Working Paper No. 260. Available at SSRN $\underline{\text { http://ssrn.com/abstract }=1399546}$

Basile, R. (2001). Export behaviour of Italian manufacturing firms over the nineties: the role of innovation. Research Policy 30, 1185-1201.

Bennedsen, M., K. Nielsen, F. Perez-Gonzalez and D. Wolfenzon (2007). The Role of Families in Succession Decisions and Performance. Quarterly Journal of Economics, vol. 22 , no. 2, pp. 674-691

Bernard, A.B., Eaton, J., Jensen, J.B., Kortum, S.S., (2003). Plants and productivity in international trade. American Economic Review 93 (4), 1268-1290.

Bernard, A.B., Jensen, J.B. (1995). Exporters, jobs, and wages in U.S. Manufacturing, 1976-1987. Bookings Papers on Economic Activity, Microeconomics. Washington DC

Bernard, Andrew B. and J. Bradford Jensen (1999). Exceptional Exporter Performance: Cause, Effect, or Both? Journal of International Economics 47, pp. 1-25.

Bernard A.B. e J.B. Jensen (2004a), Exporting and Productivity in the USA, Oxford Review of Economic Policy, vol. 20, n. 3, pp. 343-57.

Bernard, A.B. \& J. B. Jensen (2004b), "Why Some Firms Export", The Review of Economics and Statistics, Volume 86, Number 2 (May), pp. 561-569.

Bernard, A.B., J.B., Jensen, and P.K. Schott (2006) .Trade costs, firms and productivity. Journal of Monetary Economics, 53, 917-937.

Bertrand, Marianne, and Antoinette Schoar. (2006). The Role of Family in Family Firms. Journal of Economic Perspectives, 20(2): 73-96 
Bernard, Andrew B., Joachim Wagner (1997). Exports and success in German manufacturing. Weltwirtschaftliches Archiv 133, pp. 134-157

Bleaney M., K. Wakelin. (2002). Efficiency, innovation and exports. Oxford Bulletin of Economics \& Statistics, Volume 64, Number 1 (February), pp. 1-15

Bloom N. e J. Van Reenen (2007), Measuring and Explaining Management Practices across Firms and Countries, The Quarterly Journal of Economics, vol. 122, n. 4, pp. 13511408 .

Bugamelli M. and L. Infante, (2003) Sunk Costs of Exports. Temi di discussione (Economic working papers) No. 469, Bank of Italy.

Burkart, Mike C., Panunzi, Fausto and Shleifer, Andrei, (2003) Family Firms. Journal of Finance, Vol. 58, pp. 2167-2202.

Campa J.M. (2004), Exchange Rates and Trade: How Important Is Hysteresis in Trade?, European Economics Review, vol. 48, n. 3, pp. 527-48.

Caselli, F. and N. Gennaioli, (2003). Dynastic Management. NBER Working paper, no. 9442.

Castellani, D., (2002). Export behavior and productivity growth: evidence from Italian manufacturing firms. Review of World Economics 138(4), 605-628.

Clerides, S., Lach, S., Tybout, J. R., (1998). Is learning by exporting important? Microdynamic evidence from Colombia, Mexico and Morocco. The Quarterly Journal of Economics 113(3), 903-947.

Dixit, A. (1989). "Hysteresis, Import Penetration, and Exchange Rate Pass-Through. Quarterly Journal of Economics CIV, pp. 205-228.

Eaton, J., S. Kortum, and F. Kramarz (2004). Dissecting trade: Firms, industries, and export destinations. American Economic Review (Papers and Proceedings) 94, 150-54.

Ellul, Andrew, Marco Pagano, and Fausto Panunzi. (2010). Inheritance Law and Investment in Family Firms. American Economic Review, 100(5): 2414-50.

Favero C. A., S. Giglio, M. Honorati, F. Panunzi (2006). The Performance of Italian Family Firms. ECGI Finance Working Paper No. 127.

Ferragina and Quintieri (2000) Caratteristiche delle imprese esportatrici italiane. Un'analisi su dati Mediocredito e Federmeccanica. Technical report 14, ICE Working paper.

Girma, S. David Greenaway \& Richard Kneller (2004). Does Exporting Increase Productivity? A Microeconometric Analysis of Matched Firms. Review of International Economics, 12(5), 855-866.

Greenaway, D., R Kneller (2007). Firm heterogeneity, exporting and foreign direct investment. The Economic Journal, Volume 117, Number 517 (February), pp. F134-F161. 
Helpman, E.; M. J. Melitz and S. R. Yeaple (2004). Exports vs. FDI with heterogeneous firms. American Economic Review, 94 (1), 300-316.

ISGEP - International Study Group on Exports and Productivity (2008), Understanding Cross-Country Differences in Exporter Premia - Comparable Evidence for 14 Countries, Review of World Economics, vol. 144, n. 4.

Krugman P.R. (1989), Exchange Rate Stability, Cambridge, MIT Press, Cambridge, MA.

Marin, D. and T. Verdier (2003). Globalization and the 'New Enterprise. Journal of the European Economic Association, 2003 1(2-3), pp. 337-44

Marin D. and T. Verdier (2006). Corporate Hierarchies and International Trade: Theory and Evidence. PSE mimeo.

Mayer, T. and G. Ottaviano (2007). The Happy Few: The Internationalization of European Firms. Bruegel Blueprint Series, Volume III.

Mion, G. and L. D. Opromolla (2011). Managers' Mobility, Trade Status and Wages. CEPR Discussion Paper No 8230.

Melitz, M.J., (2003). The impact of trade on intra-industry reallocations and aggregate industry productivity". Econometrica 71, 1695-1725

Melitz, M. and G. Ottaviano (2008) Market size, trade and productivity, Review of Economic Studies, 2008, Vol. 75, pp. 295 - 316.

Perez-Gonzalez, F. (2006). Inherited Control and Firm Performance. American Economic Review, December 2006, Vol. 96, No. 5, pp. 1559-1588.

Poddar, Tushar, (2004). Domestic Competition Spurs Exports: The Indian Example. IMF Working Paper, no. 04/173, pp. 1-29. Available at SSRN: http://ssrn.com/abstract $=878998$

Roberts, Mark J. and James R. Tybout (1997). The Decision to Export in Colombia: An Empirical Model of Entry with Sunk Costs. American Economic Review 87, pp. 545564.

Serti, F. and C. Tomasi (2008) Self-Selection and Post-Entry Effects of Exports: Evidence from Italian Manufacturing Firms. Review of World Economics 144 (4), 660-694.

Sraer D., Thesmar D. (2006). Performance and Behavior of Family Firms: Evidence from the French Stock Market. ECGI Working Paper No. 130/2006, http://ssrc.com/abstract id $=925415$

Sterlacchini, Alessandro (2001). The determinants of export performance: A firm-leve study of Italian manufacturing. Review of World Economics (Weltwirtschaftliches Archiv), Springer, vol. 137(3), pages 450-472. 


\section{APPENDIX A: DATA DESCRIPTION}

We use the firm level EU-Efige/Bruegel-UniCredit dataset. The data have been collected within the project Efige - European Firms in a Global Economy: internal policies for external competitiveness - supported by the Directorate General Research of the European Commission through its FP7 program. GFK Eurisko dealt with the collection of data via CATI (Computer Assisted Telephone Interview) and CAWI (Computer Assisted Web Interview). This database collects information for seven European Countries - Austria, France, Germany, Hungary, Italy, Spain and United Kingdom - and provides insights on the following firm characteristics and activities: structure of the firm; workforce; investment, technological innovation and $R \& D$; internationalization; finance; market and pricing.

The sampling design has followed a stratification by sector and firm size, it covers firms with at least 10 employees. All elaborations and regressions on data have been computed using weights to report the sample to the national firm universe.

We define as a "family firm" all firms replying "yes" to the question "Is your firm directly or indirectly controlled by an individual or family-owned entity?" and firms declaring that at least $30 \%$ of their capital is held by an individual/group of individuals (wide-definition).

In order to have a proxy for the exporters, we consider the replies to the following two questions: "has the firm sold abroad some or all of its own products / services in 2008?" and "before 2008, has the firm exported any of its products?". A firm is termed "exporter" if it replies "yes, directly from the home country" to the first question and "regularly/always" or "sometimes" to the second. We felt that using only the first question to define exporters might exclude firms that only temporarily stopped selling abroad, given that 2008 has witnessed an extraordinary contraction in international trade.

When we consider exporters to China and India, we have to rely solely on the export activity in 2008, since the breakup by geographical destination of international activity is available only for that year. ${ }^{13}$

The survey data have been matched with balance sheet data from Amadeus (Bureau van Dyck) to construct a measure of labour productivity.

\footnotetext{
${ }^{13}$ For more information about the sampling construction, the collection of data, the sample characteristics and the weighting procedure see Barba et al. (2010).
} 


\section{APPENDIX B: Tables and graphs}

Table A1: Sample distribution by country

\begin{tabular}{|l|c|}
\hline Country & Number of firms \\
\hline AUT & 482 \\
FRA & 2,973 \\
GER & 2,973 \\
HUN & 488 \\
ITA & 3,021 \\
SPA & 2,832 \\
UK & 2,142 \\
\hline Total & 14,911 \\
\hline
\end{tabular}

Source: Authors' elaborations from EU-EFIGE/Bruegel-UniCredit dataset 
Table A2: Variables definitions

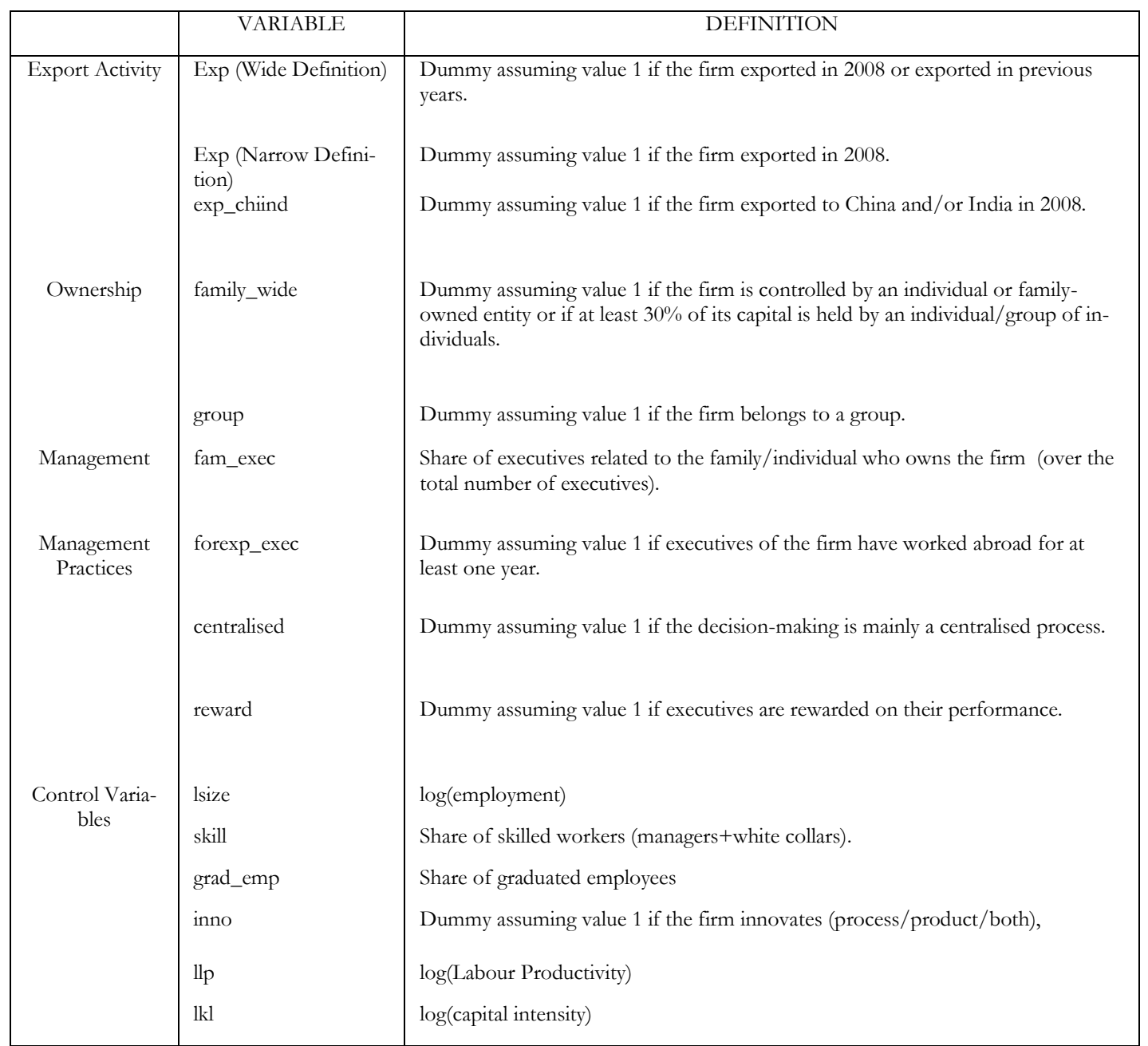

If not differently specified, variables refer to the year 2008 . 
Table A3: The geographical distribution of exporters

\begin{tabular}{|c|c|c|c|c|c|c|}
\hline \multirow[b]{2}{*}{ country } & \multicolumn{4}{|c|}{ Over the Whole Population } & \multicolumn{2}{|c|}{ Over Exporters' Popul } \\
\hline & $\begin{array}{l}\text { Share of } \\
\text { exporters. } \\
\text { Wide } \\
\text { definition }\end{array}$ & $\begin{array}{l}\text { Share of } \\
\text { exporters. } \\
\text { Narrow } \\
\text { definition }\end{array}$ & $\begin{array}{l}\text { Share of } \\
\text { Exporters to } \\
\text { China and } \\
\text { India }\end{array}$ & $\begin{array}{c}\text { Share of } \\
\text { Exporters to } \\
\text { markets } \\
\text { Outside } \\
\text { Europe excl. } \\
\text { China/India }\end{array}$ & $\begin{array}{l}\text { Share of } \\
\text { Exporters to } \\
\text { China and } \\
\text { India }\end{array}$ & $\begin{array}{c}\text { Share of } \\
\text { Exporters to } \\
\text { markets } \\
\text { Outside } \\
\text { Europe excl. } \\
\text { China/India }\end{array}$ \\
\hline AUT & 73.2 & 54.8 & 9.8 & 10.7 & 17.8 & 19.5 \\
\hline FRA & 58.5 & 45.4 & 10.1 & 18.0 & 22.2 & 39.7 \\
\hline GER & 60.0 & 41.2 & 11.2 & 11.4 & 27.3 & 27.7 \\
\hline HUN & 67.3 & 49.0 & 0.8 & 7.0 & 1.6 & 14.4 \\
\hline ITA & 72.2 & 63.5 & 11.2 & 25.9 & 17.7 & 40.9 \\
\hline SPA & 61.1 & 47.9 & 5.2 & 21.1 & 10.8 & 44.1 \\
\hline UK & 64.0 & 55.6 & 14.4 & 23.7 & 25.8 & 42.7 \\
\hline Total & 64.4 & 51.4 & 10.2 & 19.2 & 19.9 & 37.4 \\
\hline
\end{tabular}

Source: Authors' elaborations from EU-EFIGE/Bruegel-UniCredit dataset

Share of exporters over the whole population are defined both according to the narrow and the wide definition of exporter (see Table A2). Share of exporters according to the narrow definition and destination-specific shares of exporters are defined for the export activity in 2008. Share of exporters according to the wide definition capture the firm export activity in both 2008 and previous years.

Share of Exporters to Countries Outside Europe does not include firms exporting to China and India.

Table A4: Exporters characteristics: averages by destination markets

\begin{tabular}{|l|r|r|r|r|r|r|}
\hline \multicolumn{1}{|c|}{ Variable } & Non Exporters & Exporters & diff & $\begin{array}{r}\text { Exporters to all } \\
\text { countries } \\
\text { excluding } \\
\text { China/India }\end{array}$ & $\begin{array}{r}\text { Exporters to } \\
\text { China/India }\end{array}$ & diff \\
\hline labour productivity & 116.88 & 152.32 & a & 152.27 & 163.41 & ns \\
size & 39 & 83 & a & 73 & 123 & a \\
family & 0.75 & 0.73 & a & 0.73 & 0.67 & a \\
family_wide & 0.89 & 0.84 & a & 0.84 & 0.78 & a \\
fam_exec & 54.17 & 45.92 & a & 47.98 & 36.88 & a \\
centralised & 0.79 & 0.71 & $\mathrm{a}$ & 0.72 & 0.65 & $\mathrm{a}$ \\
reward & 0.28 & 0.39 & $\mathrm{a}$ & 0.36 & 0.50 & $\mathrm{a}$ \\
forexp_exec & 0.10 & 0.25 & $\mathrm{a}$ & 0.23 & 0.35 & $\mathrm{a}$ \\
group & 0.12 & 0.21 & $\mathrm{a}$ & 0.20 & 0.33 & $\mathrm{a}$ \\
\hline
\end{tabular}

Source: Authors' elaborations from EU-EFIGE/Bruegel-UniCredit dataset

Columns diff report the significance level of a t-test on the equality of means between the groups Exporters/NonExporters and the groups Exporters to China and India/ Exporters to Other Countries. $a, b, c$ Significant at $1 \%, 5 \%$ and $10 \%, n s$ not-significant. 
Fig. A1:

China's weight in total export of each country/group

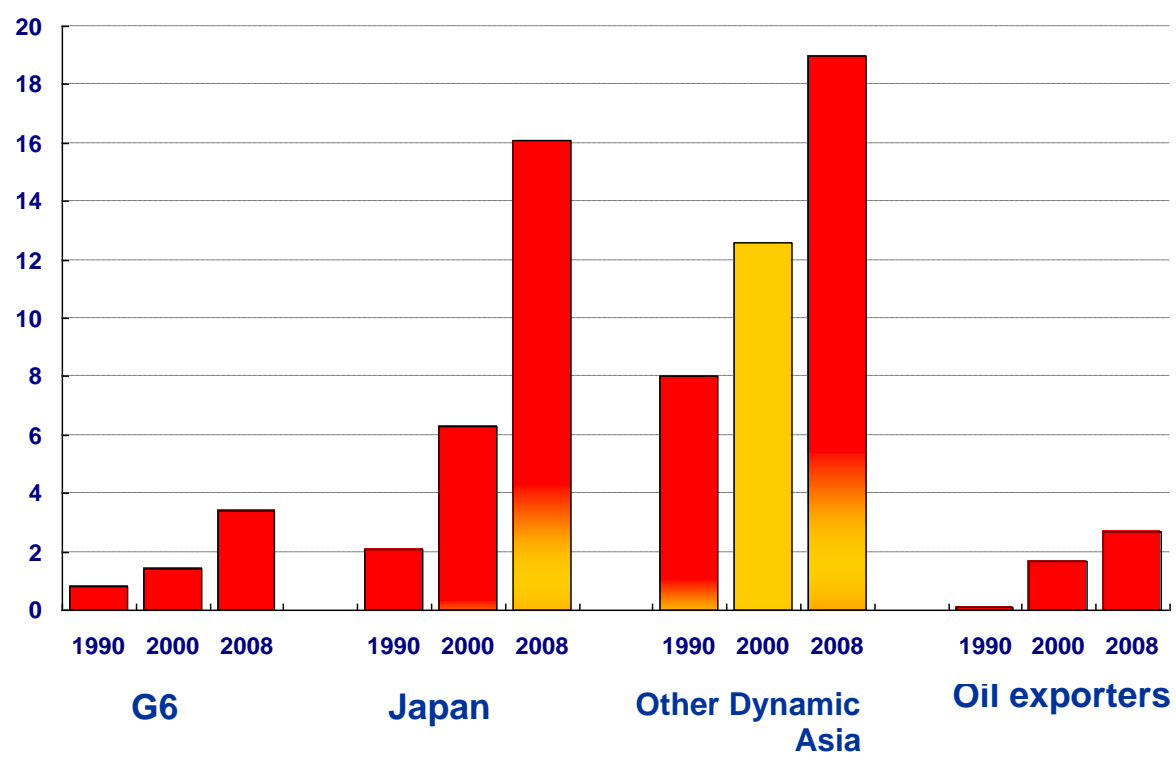

Fig. A2:

China's weight in total export of each country/group

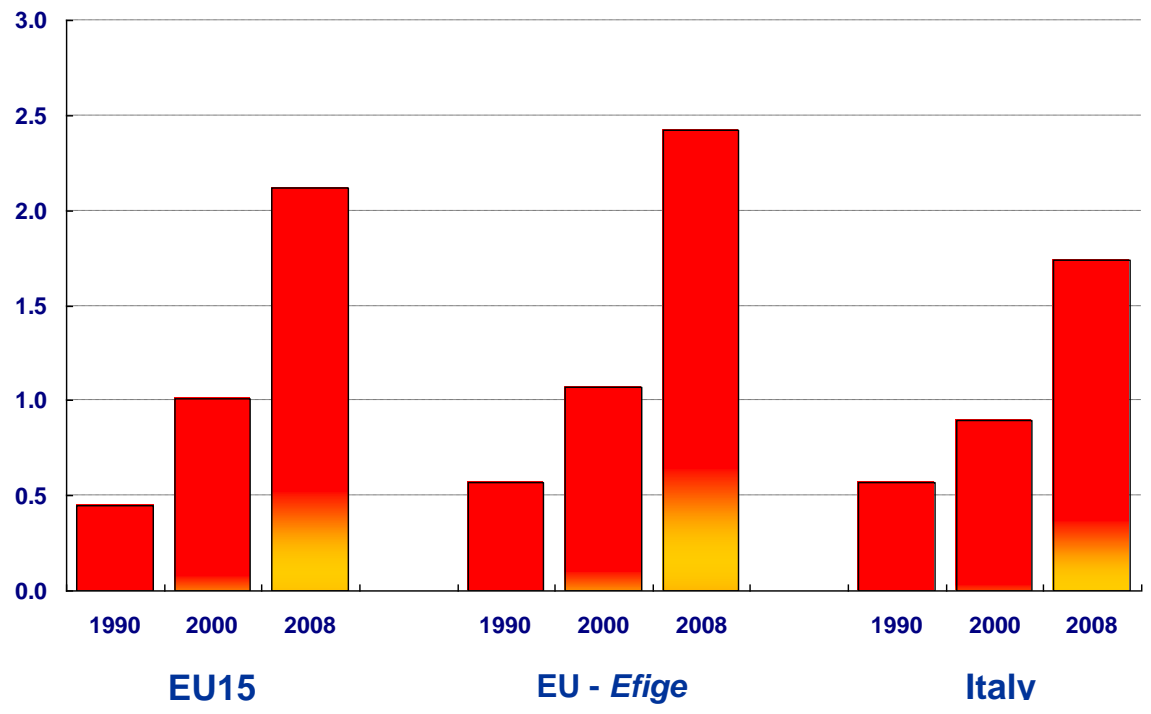


Fig. A3: Percentage of exporting firms by destination market

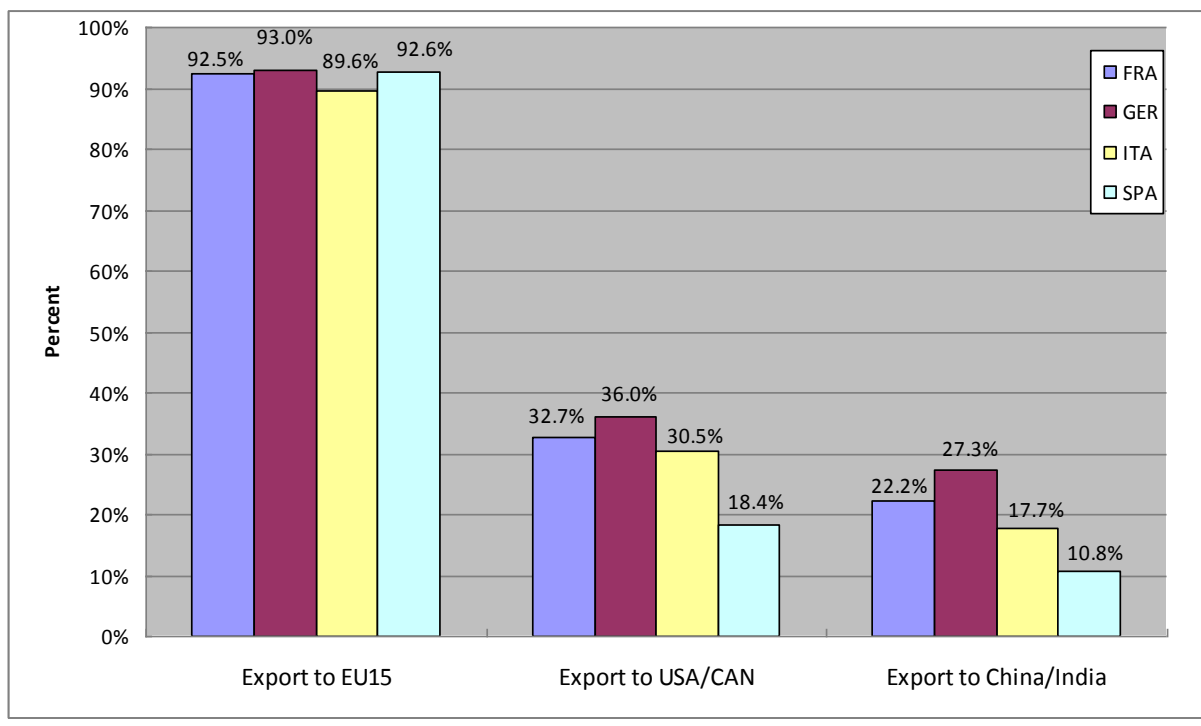

Source: Authors' elaborations from EU-EFIGE/Bruegel-UniCredit dataset. The Table shows the geographical distribution of exporters. 
Table A5: Export extensive margin: probit regression on all firms

\begin{tabular}{|c|c|c|c|c|c|c|c|}
\hline \multirow{2}{*}{ VARIABLES } & (1) & (2) & (3) & (4) & (5) & (6) & (7) \\
\hline & $\mathrm{a}$ & b & c & d & e & $\mathrm{f}$ & $\mathrm{g}$ \\
\hline \multirow[t]{2}{*}{ lsize } & & & $0.335^{* * * *}$ & $0.327^{* * * *}$ & $0.333^{* * * *}$ & $0.301^{* * * *}$ & $0.284^{* * * *}$ \\
\hline & & & {$[0.015]$} & {$[0.021]$} & {$[0.021]$} & {$[0.021]$} & {$[0.022]$} \\
\hline \multirow[t]{2}{*}{ llp2 } & & & & $0.241^{* * *}$ & $0.217^{* * * *}$ & $0.218^{* * * *}$ & $0.207^{* * * *}$ \\
\hline & & & & {$[0.025]$} & {$[0.025]$} & {$[0.025]$} & {$[0.027]$} \\
\hline \multirow[t]{2}{*}{ grad_emp } & & & & & $0.010^{* * *}$ & $0.008^{* * * *}$ & $0.009^{* * * *}$ \\
\hline & & & & & {$[0.002]$} & {$[0.002]$} & {$[0.002]$} \\
\hline \multirow[t]{2}{*}{ inno } & & & & & & $0.471^{* * * *}$ & $0.439^{* * * *}$ \\
\hline & & & & & & [0.037] & {$[0.038]$} \\
\hline \multirow[t]{2}{*}{ lkl } & & & & & & & $0.052^{* * * *}$ \\
\hline & & & & & & & [0.015] \\
\hline \multirow[t]{2}{*}{ AUT } & $0.365^{* * *}$ & $0.460^{* * *}$ & $0.472^{* * *}$ & $0.501^{* * *}$ & $0.549^{* * *}$ & $0.480^{* * * *}$ & $0.438^{* *}$ \\
\hline & {$[0.082]$} & [0.093] & {$[0.096]$} & {$[0.173]$} & {$[0.172]$} & {$[0.164]$} & [0.197] \\
\hline \multirow[t]{2}{*}{ FRA } & -0.037 & -0.019 & 0.017 & -0.064 & -0.056 & -0.036 & -0.079 \\
\hline & [0.039] & [0.039] & {$[0.040]$} & {$[0.046]$} & {$[0.046]$} & {$[0.046]$} & {$[0.050]$} \\
\hline \multirow[t]{2}{*}{ HUN } & $0.195^{* * *}$ & $0.239^{* * *}$ & $0.255^{* * *}$ & $0.529^{* * *}$ & $0.436^{* * *}$ & $0.460^{* * * *}$ & $0.363^{* * * *}$ \\
\hline & {$[0.068]$} & {$[0.070]$} & {$[0.071]$} & {$[0.105]$} & {$[0.107]$} & [0.109] & {$[0.112]$} \\
\hline \multirow[t]{2}{*}{ ITA } & $0.335^{* * * *}$ & $0.282^{* * *}$ & $0.369^{* * *}$ & $0.260^{* * *}$ & $0.293^{* * *}$ & $0.264^{* * * *}$ & $0.170^{* * * *}$ \\
\hline & {$[0.036]$} & {$[0.037]$} & {$[0.038]$} & {$[0.043]$} & {$[0.044]$} & {$[0.044]$} & {$[0.051]$} \\
\hline \multirow[t]{2}{*}{ SPA } & 0.028 & 0.056 & $0.132^{* * *}$ & $0.095^{* *}$ & $0.077^{*}$ & 0.036 & -0.052 \\
\hline & {$[0.036]$} & [0.037] & {$[0.038]$} & {$[0.046]$} & [0.046] & [0.047] & {$[0.052]$} \\
\hline \multirow[t]{2}{*}{ UK } & $0.105^{* * *}$ & 0.060 & $0.085^{* *}$ & $0.284^{* * *}$ & $0.257^{* * *}$ & $0.219^{* *}$ & 0.161 \\
\hline & {$[0.039]$} & {$[0.040]$} & {$[0.040]$} & {$[0.098]$} & {$[0.098]$} & [0.099] & {$[0.101]$} \\
\hline \multirow[t]{2}{*}{ Constant } & $0.253^{* * * *}$ & $-0.167^{* * * *}$ & $-1.337^{* * *}$ & $-2.358^{* * *}$ & $-2.340^{* * *}$ & $-2.526^{* * *}$ & $-2.434^{* * *}$ \\
\hline & {$[0.025]$} & [0.042] & {$[0.070]$} & [0.152] & [0.150] & {$[0.152]$} & {$[0.160]$} \\
\hline Observations & 14910 & 14723 & 14723 & 10246 & 10241 & 10241 & 9702 \\
\hline Pseudo-R2 & 0.011 & 0.065 & 0.096 & 0.118 & 0.124 & 0.145 & 0.140 \\
\hline Wald Chi2 & 146.9 & 958.9 & 1363 & 932.1 & 989.7 & 1146 & 1050 \\
\hline Log-likelihood & -9602 & -8953 & -8654 & -5720 & -5680 & -5545 & -5227 \\
\hline
\end{tabular}

Probit Estimations. The dependent variable is a dummy capturing the export status of firms in 2008 and/or previous years. All estimations include two-digit NACE dummies and are run on the weighted sample. The drop of the number of observations across columns is due to missing data for the firm level variables used in the regressions. Robust standard errors in brackets. ***, **, * significant at 1\%, 5\%, 10\%. See Table A2 for the definition of variables. 
Table A6: Export intensive margin: OLS regression on all firms (Only Ex-

\begin{tabular}{|c|c|c|c|c|c|c|c|}
\hline \multirow{2}{*}{ VARIABLES } & \multicolumn{7}{|c|}{ (3) } \\
\hline & a & $\mathrm{b}$ & c & d & e & $\mathrm{f}$ & $\mathrm{g}$ \\
\hline \multirow[t]{2}{*}{ lsize } & & & $1.261^{* * *}$ & $1.207^{* * *}$ & $1.216^{* * * *}$ & $1.208^{* * *}$ & $1.195^{* * *}$ \\
\hline & & & {$[0.027]$} & {$[0.021]$} & {$[0.020]$} & {$[0.020]$} & {$[0.022]$} \\
\hline \multirow[t]{2}{*}{ llp2 } & & & & $0.917^{* * * *}$ & $0.887^{* * * *}$ & $0.889^{* * * *}$ & $0.850^{* * * *}$ \\
\hline & & & & {$[0.033]$} & {$[0.032]$} & {$[0.032]$} & {$[0.035]$} \\
\hline \multirow[t]{2}{*}{ grad_emp } & & & & & $0.014^{* * *}$ & $0.013^{* * *}$ & $0.013^{* * * *}$ \\
\hline & & & & & {$[0.002]$} & {$[0.002]$} & {$[0.002]$} \\
\hline \multirow[t]{2}{*}{ inno } & & & & & & $0.161^{* * *}$ & $0.156^{* * * *}$ \\
\hline & & & & & & {$[0.055]$} & {$[0.056]$} \\
\hline \multirow[t]{2}{*}{ lkl } & & & & & & & $0.059^{* * * *}$ \\
\hline & & & & & & & {$[0.021]$} \\
\hline \multirow[t]{2}{*}{ AUT } & 0.072 & 0.160 & 0.168 & $0.243^{*}$ & $0.314^{* *}$ & $0.293^{* *}$ & $0.336^{* *}$ \\
\hline & {$[0.252]$} & {$[0.222]$} & [0.163] & [0.140] & {$[0.141]$} & [0.141] & [0.149] \\
\hline \multirow[t]{2}{*}{ FRA } & $-0.323^{* * *}$ & $-0.373^{* * *}$ & $-0.267^{* * *}$ & -0.018 & -0.033 & -0.021 & -0.018 \\
\hline & {$[0.092]$} & [0.086] & [0.067] & [0.059] & {$[0.058]$} & {$[0.058]$} & {$[0.061]$} \\
\hline \multirow[t]{2}{*}{ HUN } & $-0.785^{* * *}$ & $-0.706^{* * *}$ & $-0.722^{* * *}$ & $0.478^{* * *}$ & $0.396^{* * * *}$ & $0.418^{* * *}$ & $0.344^{* * *}$ \\
\hline & [0.199] & [0.193] & {$[0.143]$} & {$[0.122]$} & {$[0.122]$} & {$[0.122]$} & {$[0.126]$} \\
\hline \multirow[t]{2}{*}{ ITA } & $-0.162^{* *}$ & $-0.164^{* *}$ & $0.312^{* * *}$ & $0.249^{* * * *}$ & $0.299^{* * * *}$ & $0.293^{* * *}$ & $0.229^{* * * *}$ \\
\hline & {$[0.075]$} & {$[0.072]$} & {$[0.060]$} & {$[0.050]$} & {$[0.050]$} & {$[0.050]$} & {$[0.058]$} \\
\hline \multirow[t]{2}{*}{ SPA } & $-0.821^{* * *}$ & $-0.808^{* * *}$ & $-0.438^{* * *}$ & $-0.148^{* *}$ & $-0.177^{* * * *}$ & $-0.183^{* * *}$ & $-0.245^{* * *}$ \\
\hline & {$[0.088]$} & {$[0.084]$} & {$[0.069]$} & {$[0.061]$} & {$[0.060]$} & {$[0.060]$} & {$[0.065]$} \\
\hline \multirow[t]{2}{*}{ UK } & -0.098 & -0.044 & -0.047 & 0.050 & 0.000 & -0.007 & -0.008 \\
\hline & [0.148] & [0.134] & [0.127] & {$[0.117]$} & {$[0.114]$} & {$[0.114]$} & {$[0.116]$} \\
\hline \multirow[t]{2}{*}{ Constant } & $7.172^{* * * *}$ & $7.065^{* * *}$ & $2.289^{* * * *}$ & $-2.252^{* * *}$ & $-2.276^{* * *}$ & $-2.375^{* * *}$ & $-2.299^{* * *}$ \\
\hline & {$[0.062]$} & {$[0.115]$} & {$[0.150]$} & {$[0.202]$} & [0.195] & {$[0.197]$} & {$[0.204]$} \\
\hline Observations & 5752 & 5694 & 5694 & 5537 & 5533 & 5533 & 5316 \\
\hline R-squared & 0.019 & 0.108 & 0.451 & 0.584 & 0.592 & 0.593 & 0.581 \\
\hline
\end{tabular}

OLS Estimations. The dependent variable is the log of the firm export value recorded in 2008 for exporters. All estimations include two-digit NACE dummies and are run on the weighted sample. The drop of the number of observations across columns is due to missing data for the firm level variables used in the regressions. Robust standard errors in brackets. ${ }^{* *},{ }^{* *}, *$ significant at $1 \%, 5 \%, 10 \%$.

See Table A2 for the definition of variables. 
Table A7: Export extensive margin in China and India: probit regression, only

\begin{tabular}{|c|c|c|c|c|c|c|c|}
\hline \multicolumn{8}{|c|}{$\begin{array}{c}\text { exporters } \\
\end{array}$} \\
\hline \multirow{2}{*}{ VARIABLES } & (1) & $(2)$ & (3) & $(4)$ & (5) & (6) & (7) \\
\hline & $\mathrm{a}$ & $\mathrm{b}$ & $\mathrm{c}$ & $\mathrm{d}$ & $\mathrm{e}$ & $\mathrm{f}$ & $\mathrm{g}$ \\
\hline \multirow[t]{2}{*}{ lsize } & & & $0.196^{* * *}$ & $0.155^{* * *}$ & $0.161^{* * *}$ & $0.152^{* * *}$ & $0.134^{* * * *}$ \\
\hline & & & {$[0.017]$} & {$[0.025]$} & {$[0.025]$} & {$[0.025]$} & {$[0.026]$} \\
\hline \multirow[t]{2}{*}{ llp2 } & & & & $0.077^{*}$ & 0.055 & 0.059 & $0.076^{* *}$ \\
\hline & & & & [0.041] & {$[0.040]$} & {$[0.040]$} & [0.037] \\
\hline \multirow[t]{2}{*}{ grad_emp } & & & & & $0.010^{* * * *}$ & $0.009^{* * *}$ & $0.009^{* * * *}$ \\
\hline & & & & & {$[0.002]$} & {$[0.002]$} & {$[0.002]$} \\
\hline \multirow[t]{2}{*}{ inno } & & & & & & $0.252^{* * *}$ & $0.247^{* * * *}$ \\
\hline & & & & & & {$[0.057]$} & [0.059] \\
\hline \multirow[t]{2}{*}{ lkl } & & & & & & & 0.012 \\
\hline & & & & & & & {$[0.023]$} \\
\hline \multirow[t]{2}{*}{ AUT } & $-0.320^{* * * *}$ & $-0.368^{* * *}$ & $-0.384^{* * *}$ & -0.195 & -0.137 & -0.173 & -0.178 \\
\hline & [0.109] & [0.111] & [0.111] & [0.162] & [0.165] & [0.164] & [0.177] \\
\hline \multirow[t]{2}{*}{ FRA } & $-0.161^{* * *}$ & $-0.114^{*}$ & -0.095 & -0.033 & -0.044 & -0.027 & -0.037 \\
\hline & [0.057] & {$[0.060]$} & {$[0.061]$} & {$[0.069]$} & {$[0.070]$} & {$[0.070]$} & {$[0.073]$} \\
\hline \multirow[t]{2}{*}{ HUN } & $-1.542^{* * *}$ & $-1.483^{* * *}$ & $-1.520^{* * *}$ & $-1.401^{* * * *}$ & $-1.475^{* * *}$ & $-1.454^{* * *}$ & $-1.446^{* * *}$ \\
\hline & [0.180] & [0.183] & [0.190] & {$[0.247]$} & {$[0.241]$} & {$[0.240]$} & {$[0.241]$} \\
\hline \multirow[t]{2}{*}{ ITA } & $-0.323^{* * * *}$ & $-0.282^{* * *}$ & $-0.203^{* * *}$ & $-0.216^{* * *}$ & $-0.176^{* * *}$ & $-0.186^{* * *}$ & $-0.216^{* * *}$ \\
\hline & {$[0.050]$} & [0.052] & [0.053] & {$[0.060]$} & {$[0.060]$} & [0.061] & {$[0.068]$} \\
\hline \multirow[t]{2}{*}{ SPA } & $-0.636^{* * *}$ & $-0.562^{* * *}$ & $-0.510^{* * *}$ & $-0.494^{* * *}$ & $-0.520^{* * * *}$ & $-0.531^{* * *}$ & $-0.544^{* * *}$ \\
\hline & [0.059] & [0.062] & [0.063] & {$[0.075]$} & {$[0.075]$} & [0.076] & {$[0.081]$} \\
\hline \multirow[t]{2}{*}{ UK } & -0.045 & -0.021 & 0.018 & $0.191^{*}$ & 0.165 & 0.149 & 0.095 \\
\hline & {$[0.054]$} & [0.056] & {$[0.057]$} & {$[0.110]$} & [0.109] & {$[0.108]$} & [0.111] \\
\hline \multirow[t]{2}{*}{ Constant } & $-0.604^{* * * *}$ & $-0.956^{* * *}$ & $-1.721^{* * *}$ & $-1.960^{* * * *}$ & $-1.981^{* * * *}$ & $-2.165^{* * *}$ & $-2.228^{* * *}$ \\
\hline & {$[0.038]$} & {$[0.082]$} & [0.113] & {$[0.245]$} & {$[0.240]$} & [0.240] & {$[0.233]$} \\
\hline Observations & 7920 & 7821 & 7821 & 5555 & 5551 & 5551 & 5329 \\
\hline Pseudo-R2 & 0.028 & 0.079 & 0.095 & 0.102 & 0.111 & 0.115 & 0.115 \\
\hline Wald Chi2 & 205.6 & 502.5 & 612.9 & 374.1 & 407.9 & 427.5 & 406.6 \\
\hline Log-likelihood & -3843 & -3595 & -3532 & -2574 & -2550 & -2536 & -2419 \\
\hline
\end{tabular}

Probit Estimations. The dependent variable is a dummy capturing the firm export activity in China and India in 2008 for exporters only. All estimations include two-digit NACE dummies and are run on the weighted sample. The drop of the number of observations across columns is due to missing data for the firm level variables used in the regressions. Robust standard errors in brackets. $* * * * *, *$ significant at $1 \%$, $5 \%, 10 \%$.

See Table A2 for the definition of variables. 
Table A8: Export intensive margin in China and India: OLS regression, only exporters to China and India

\begin{tabular}{|c|c|c|c|c|c|c|c|}
\hline \multirow{2}{*}{ VARIABLES } & (1) & (2) & (3) & (4) & (5) & (6) & (7) \\
\hline & a & $\mathrm{b}$ & c & $\mathrm{d}$ & e & $\mathrm{f}$ & $\mathrm{g}$ \\
\hline \multirow[t]{2}{*}{ lsize } & & & $0.980^{* * *}$ & $0.953^{* * *}$ & $0.978^{* * *}$ & $0.980^{* * *}$ & $0.970^{* * *}$ \\
\hline & & & {$[0.055]$} & {$[0.041]$} & {$[0.038]$} & [0.039] & {$[0.040]$} \\
\hline \multirow[t]{2}{*}{ llp2 } & & & & $0.887^{* * * *}$ & $0.834^{* * *}$ & $0.832^{* * *}$ & $0.786^{\text {*** }}$ \\
\hline & & & & {$[0.083]$} & {$[0.077]$} & {$[0.077]$} & [0.089] \\
\hline \multirow[t]{2}{*}{ grad_emp } & & & & & $0.019^{* * * *}$ & $0.019^{* * * *}$ & $0.019^{* * * *}$ \\
\hline & & & & & {$[0.004]$} & {$[0.004]$} & {$[0.004]$} \\
\hline \multirow[t]{2}{*}{ inno } & & & & & & -0.072 & -0.080 \\
\hline & & & & & & [0.125] & [0.129] \\
\hline \multirow[t]{2}{*}{ lkl } & & & & & & & 0.067 \\
\hline & & & & & & & {$[0.048]$} \\
\hline \multirow[t]{2}{*}{ AUT } & $0.763^{*}$ & $0.716^{*}$ & $0.664^{*}$ & $0.550^{*}$ & $0.696^{* *}$ & $0.713^{* *}$ & $0.931^{* * *}$ \\
\hline & [0.449] & {$[0.424]$} & [0.363] & [0.308] & [0.309] & {$[0.310]$} & {$[0.326]$} \\
\hline \multirow[t]{2}{*}{ FRA } & $-0.534^{* * *}$ & $-0.561^{* * *}$ & $-0.352^{* *}$ & -0.180 & -0.201 & -0.203 & -0.123 \\
\hline & {$[0.180]$} & [0.170] & [0.141] & {$[0.136]$} & [0.134] & [0.133] & [0.139] \\
\hline \multirow[t]{2}{*}{ HUN } & -0.394 & -0.523 & -0.416 & $0.781^{* * * *}$ & 0.385 & 0.393 & $0.434^{*}$ \\
\hline & {$[0.600]$} & [0.706] & [0.395] & [0.197] & {$[0.251]$} & {$[0.254]$} & [0.240] \\
\hline \multirow[t]{2}{*}{ ITA } & $-0.286^{* *}$ & $-0.314^{* *}$ & 0.173 & 0.088 & 0.195 & 0.197 & $0.221^{*}$ \\
\hline & [0.139] & {$[0.146]$} & [0.129] & [0.124] & {$[0.120]$} & {$[0.120]$} & [0.131] \\
\hline \multirow[t]{2}{*}{ SPA } & $-0.726^{* * *}$ & $-0.682^{* * * *}$ & $-0.465^{* * *}$ & $-0.284^{*}$ & $-0.359^{* *}$ & $-0.356^{* *}$ & $-0.330^{*}$ \\
\hline & {$[0.207]$} & [0.211] & [0.175] & [0.172] & {$[0.171]$} & {$[0.170]$} & [0.177] \\
\hline \multirow[t]{2}{*}{ UK } & $-0.501^{*}$ & $-0.445^{*}$ & 0.008 & 0.268 & 0.126 & 0.136 & 0.193 \\
\hline & {$[0.256]$} & {$[0.242]$} & {$[0.233]$} & [0.192] & {$[0.182]$} & {$[0.184]$} & [0.193] \\
\hline \multirow[t]{2}{*}{ Constant } & $5.929^{* * * *}$ & $5.248^{* * *}$ & $1.269^{* * * *}$ & $-3.320^{* * * *}$ & $-3.402^{* * *}$ & $-3.337^{* * *}$ & $-3.344^{* * *}$ \\
\hline & {$[0.100]$} & {$[0.308]$} & [0.317] & {$[0.514]$} & [0.492] & {$[0.511]$} & [0.533] \\
\hline Observations & 1190 & 1176 & 1176 & 1151 & 1151 & 1151 & 1094 \\
\hline R-squared & 0.022 & 0.084 & 0.363 & 0.485 & 0.508 & 0.508 & 0.487 \\
\hline
\end{tabular}

OLS Estimations. The dependent variable is the log of the firm export value to China and India recorded in 2008 for exporters in those countries. All estimations include two-digit NACE dummies and are run on the weighted sample. The drop of the number of observations across columns is due to missing data for the firm level variables used in the regressions. Robust standard errors in brackets. ***, **, * significant at $1 \%, 5 \%, 10 \%$.

See Table A2 for the definition of variables. 
Table A9: Share of family firms by country

\begin{tabular}{|l|c|c|r|}
\hline \multicolumn{3}{|c|}{ Family firms by country: "narrow" and "wide" definition } \\
\hline country & Narrow & Wide & Wide - Narrow \\
\hline AUT & 82.39 & 87.69 & 5.30 \\
FRA & 57.58 & 81.03 & 23.44 \\
GER & 83.87 & 90.88 & 7.01 \\
HUN & 55.67 & 81.79 & 26.12 \\
ITA & 75.60 & 86.81 & 11.21 \\
SPA & 76.45 & 83.54 & 7.09 \\
UK & 64.52 & 82.55 & 18.03 \\
\hline \hline Total & 73.73 & 85.98 & 12.25 \\
\hline (1) "narrow": family firms i.e. firms that declared to have a family ownership; "wide": includes family \\
firms and firms having an individual as the main shareholder (capital share>=30\%) \\
\hline
\end{tabular}

Source: Authors' elaborations from EU-EFIGE/Bruegel-UniCredit dataset. 
Table A10: Export extensive margin: probit regression on all firms with "family" variables

\begin{tabular}{|c|c|c|c|c|}
\hline & (1) & (2) & (3) & (4) \\
\hline VARIABLES & $\mathrm{a}$ & $\mathrm{b}$ & c & $\mathrm{d}$ \\
\hline \multirow[t]{2}{*}{ 1lp2 } & $0.214^{* * *}$ & $0.211^{* * *}$ & $0.209^{* * *}$ & $0.207^{* * *}$ \\
\hline & [0.025] & [0.025] & {$[0.026]$} & [0.027] \\
\hline \multirow[t]{2}{*}{ lsize } & $0.295^{* * *}$ & $0.284^{* * *}$ & $0.279 * * *$ & $0.257^{* * *}$ \\
\hline & {$[0.021]$} & [0.022] & [0.023] & [0.023] \\
\hline \multirow[t]{2}{*}{ grad_emp } & $0.008^{* * *}$ & $0.008^{* * *}$ & $0.009^{* * *}$ & $0.008^{* * *}$ \\
\hline & [0.002] & [0.002] & [0.002] & [0.002] \\
\hline \multirow[t]{2}{*}{ inno } & $0.475^{* * *}$ & $0.475^{* * *}$ & $0.475^{* * *}$ & $0.443^{* * *}$ \\
\hline & [0.036] & [0.036] & [0.038] & [0.039] \\
\hline \multirow[t]{2}{*}{ family_wide } & -0.068 & -0.034 & 0.030 & 0.055 \\
\hline & {$[0.054]$} & {$[0.054]$} & [0.065] & {$[0.066]$} \\
\hline \multirow[t]{2}{*}{ fam_exec } & & & $-0.001^{* *}$ & $-0.001^{* * *}$ \\
\hline & & & [0.001] & {$[0.001]$} \\
\hline \multirow[t]{2}{*}{ group } & & $0.104^{*}$ & 0.090 & 0.027 \\
\hline & & {$[0.056]$} & {$[0.060]$} & {$[0.061]$} \\
\hline \multirow[t]{2}{*}{ centralised } & & & & -0.068 \\
\hline & & & & {$[0.048]$} \\
\hline \multirow[t]{2}{*}{ forexp_exec } & & & & $0.331^{* * *}$ \\
\hline & & & & [0.053] \\
\hline \multirow[t]{2}{*}{ AUT } & $0.479^{* * *}$ & $0.470^{* * *}$ & $0.510^{* * *}$ & $0.507^{* * *}$ \\
\hline & [0.164] & [0.164] & [0.173] & [0.182] \\
\hline \multirow[t]{2}{*}{ FRA } & -0.045 & -0.062 & -0.065 & -0.003 \\
\hline & [0.047] & {$[0.048]$} & [0.049] & {$[0.051]$} \\
\hline \multirow[t]{2}{*}{ HUN } & $0.448^{* * *}$ & $0.442^{* * *}$ & $0.442^{* * *}$ & $0.402^{* * *}$ \\
\hline & [0.109] & [0.109] & [0.116] & [0.120] \\
\hline \multirow[t]{2}{*}{ ITA } & $0.258^{* * *}$ & $0.254^{* * *}$ & $0.297^{* * *}$ & $0.365^{* * *}$ \\
\hline & [0.044] & {$[0.044]$} & {$[0.048]$} & [0.050] \\
\hline \multirow[t]{2}{*}{ SPA } & 0.027 & 0.022 & 0.072 & $0.093^{*}$ \\
\hline & [0.047] & [0.047] & {$[0.052]$} & [0.053] \\
\hline \multirow[t]{2}{*}{ UK } & $0.195^{*}$ & 0.166 & 0.078 & 0.068 \\
\hline & {$[0.100]$} & {$[0.103]$} & {$[0.111]$} & {$[0.117]$} \\
\hline \multirow[t]{2}{*}{ Constant } & $-2.425^{* * *}$ & $-2.406^{* * *}$ & $-2.384^{* * *}$ & $-2.325^{* * *}$ \\
\hline & [0.165] & {$[0.166]$} & [0.181] & [0.187] \\
\hline Observations & 10231 & 10231 & 9196 & 8823 \\
\hline Pseudo-R2 & 0.145 & 0.146 & 0.148 & 0.153 \\
\hline Wald Chi2 & 1148 & 1146 & 1070 & 1075 \\
\hline Log-likelihood & -5538 & -5535 & -4973 & -4767 \\
\hline
\end{tabular}

Probit Estimations. The dependent variable is a dummy capturing the export status of firms in 2008 and/or previous years. All estimations include two-digit NACE dummies and are run on the weighted sample. The drop of the number of observations across columns is due to missing data for the firm level variables used in the regressions. Robust standard errors in brackets. ***, **, * significant at 1\%, 5\%, $10 \%$. See Table A2 for the definition of variables. 
Table A11: Export extensive margin in China and India: probit regression, only exporters with "family" variables

\begin{tabular}{|c|c|c|c|c|}
\hline \multirow{2}{*}{ VARIABLES } & (1) & \multirow{2}{*}{$\begin{array}{l}\text { (2) } \\
\mathrm{b}\end{array}$} & \multirow{2}{*}{$\begin{array}{c}\text { (3) } \\
\text { c }\end{array}$} & \multirow{2}{*}{$\begin{array}{l}\text { (4) } \\
\text { d }\end{array}$} \\
\hline & $\mathrm{a}$ & & & \\
\hline \multirow[t]{2}{*}{ llp2 } & 0.055 & 0.045 & 0.056 & 0.054 \\
\hline & {$[0.040]$} & {$[0.040]$} & {$[0.043]$} & {$[0.044]$} \\
\hline \multirow[t]{2}{*}{ lsize } & $0.143^{* * *}$ & $0.124^{* * *}$ & $0.132^{* * *}$ & $0.113^{* * *}$ \\
\hline & [0.025] & [0.027] & [0.028] & {$[0.030]$} \\
\hline \multirow[t]{2}{*}{ grad_emp } & $0.009^{* * *}$ & $0.009^{* * *}$ & $0.007^{* * *}$ & $0.006^{* * *}$ \\
\hline & [0.002] & [0.002] & [0.002] & [0.002] \\
\hline \multirow[t]{2}{*}{ inno } & $0.259^{* * *}$ & $0.260^{* * *}$ & $0.232^{* * *}$ & $0.206^{* * *}$ \\
\hline & [0.057] & [0.057] & {$[0.061]$} & {$[0.062]$} \\
\hline \multirow[t]{2}{*}{ family_wide } & $-0.119^{*}$ & -0.059 & 0.048 & 0.018 \\
\hline & {$[0.070]$} & {$[0.075]$} & {$[0.088]$} & {$[0.090]$} \\
\hline \multirow[t]{2}{*}{ fam_exec } & & & $-0.002^{* *}$ & -0.001 \\
\hline & & & [0.001] & {$[0.001]$} \\
\hline \multirow[t]{2}{*}{ group } & & $0.167^{* *}$ & $0.158^{*}$ & $0.180^{* *}$ \\
\hline & & {$[0.077]$} & [0.083] & {$[0.084]$} \\
\hline \multirow[t]{2}{*}{ centralised } & & & & -0.035 \\
\hline & & & & {$[0.065]$} \\
\hline \multirow[t]{2}{*}{ forexp_exec } & & & & $0.126^{*}$ \\
\hline & & & & {$[0.068]$} \\
\hline \multirow[t]{2}{*}{ AUT } & -0.181 & -0.201 & -0.271 & -0.300 \\
\hline & [0.164] & {$[0.164]$} & [0.175] & [0.194] \\
\hline \multirow[t]{2}{*}{ FRA } & -0.046 & -0.081 & -0.088 & -0.081 \\
\hline & {$[0.071]$} & {$[0.074]$} & [0.075] & {$[0.079]$} \\
\hline \multirow[t]{2}{*}{ HUN } & $-1.485^{* * *}$ & $-1.497^{* * *}$ & $-1.392^{* * *}$ & $-1.315^{* * *}$ \\
\hline & [0.239] & {$[0.244]$} & [0.246] & {$[0.252]$} \\
\hline \multirow[t]{2}{*}{ ITA } & $-0.195^{* * *}$ & $-0.202^{* * *}$ & $-0.158^{* *}$ & $-0.140^{* *}$ \\
\hline & {$[0.061]$} & {$[0.061]$} & [0.065] & {$[0.068]$} \\
\hline \multirow[t]{2}{*}{ SPA } & $-0.546^{* * *}$ & $-0.559^{* * *}$ & $-0.593^{* * *}$ & $-0.611^{* * *}$ \\
\hline & [0.076] & [0.076] & [0.087] & [0.089] \\
\hline \multirow[t]{2}{*}{ UK } & 0.111 & 0.053 & 0.009 & 0.018 \\
\hline & [0.110] & [0.110] & [0.122] & {$[0.131]$} \\
\hline \multirow[t]{2}{*}{ Constant } & $-2.004^{* * *}$ & $-1.955^{* * *}$ & $-2.076^{* * *}$ & $-1.937^{* * *}$ \\
\hline & {$[0.258]$} & {$[0.260]$} & {$[0.274]$} & {$[0.280]$} \\
\hline Observations & 5544 & 5544 & 4961 & 4741 \\
\hline Pseudo-R2 & 0.116 & 0.118 & 0.117 & 0.112 \\
\hline Wald Chi2 & 434.5 & 446.4 & 398.5 & 377.2 \\
\hline Log-likelihood & -2529 & -2525 & -2248 & -2158 \\
\hline
\end{tabular}

Probit Estimations. The dependent variable is a dummy capturing the firm export activity in China and India in 2008 for exporters only. All estimations include two-digit NACE dummies and are run on the weighted sample. The drop of the number of observations across columns is due to missing data for the firm level variables used in the regressions. Robust standard errors in brackets. ***, **, * significant at $1 \%$, $5 \%, 10 \%$.

See Table A2 for the definition of variables. 
Table A12: Export intensive margin: OLS regression on exporters with "family" variables

\begin{tabular}{|c|c|c|c|c|}
\hline & (1) & (2) & (3) & (4) \\
\hline VARIABLES & $\mathrm{a}$ & $\mathrm{b}$ & $\mathrm{c}$ & $\mathrm{d}$ \\
\hline \multirow[t]{2}{*}{ 1lp2 } & $0.881^{* * *}$ & $0.864^{* * *}$ & $0.847^{* * *}$ & $0.850^{* * *}$ \\
\hline & [0.032] & [0.032] & [0.033] & {$[0.034]$} \\
\hline \multirow[t]{2}{*}{ lsize } & $1.190^{* * *}$ & $1.156^{* * *}$ & $1.145^{* * *}$ & $1.106^{* * *}$ \\
\hline & {$[0.021]$} & [0.023] & [0.024] & {$[0.026]$} \\
\hline \multirow[t]{2}{*}{ grad_emp } & $0.013^{* * *}$ & $0.012^{* * *}$ & $0.012^{* * *}$ & $0.010^{* * *}$ \\
\hline & [0.002] & [0.002] & [0.002] & [0.002] \\
\hline \multirow[t]{2}{*}{ inno } & $0.165^{* * *}$ & $0.165^{* * *}$ & $0.162^{* * *}$ & $0.118^{* *}$ \\
\hline & [0.055] & {$[0.054]$} & [0.056] & {$[0.056]$} \\
\hline \multirow[t]{2}{*}{ family_wide } & $-0.210^{* * *}$ & -0.102 & -0.067 & -0.055 \\
\hline & [0.067] & [0.067] & {$[0.080]$} & {$[0.077]$} \\
\hline \multirow[t]{2}{*}{ fam_exec } & & & $-0.002^{* * *}$ & $-0.002^{* *}$ \\
\hline & & & {$[0.001]$} & [0.001] \\
\hline \multirow[t]{2}{*}{ group } & & $0.308^{* * *}$ & $0.317^{* * *}$ & $0.311^{* * *}$ \\
\hline & & [0.069] & {$[0.071]$} & [0.069] \\
\hline \multirow[t]{2}{*}{ centralised } & & & & -0.042 \\
\hline & & & & [0.053] \\
\hline \multirow[t]{2}{*}{ forexp_exec } & & & & $0.363^{* * *}$ \\
\hline & & & & [0.060] \\
\hline \multirow[t]{2}{*}{ AUT } & $0.285^{* *}$ & $0.253^{*}$ & $0.265^{*}$ & $0.263^{*}$ \\
\hline & [0.141] & [0.139] & [0.145] & [0.159] \\
\hline \multirow[t]{2}{*}{ FRA } & -0.049 & $-0.112^{*}$ & $-0.147^{* *}$ & -0.077 \\
\hline & [0.059] & {$[0.061]$} & [0.062] & {$[0.063]$} \\
\hline \multirow[t]{2}{*}{ HUN } & $0.390^{* * *}$ & $0.363^{* * *}$ & $0.338^{* * *}$ & $0.491^{* * *}$ \\
\hline & [0.123] & [0.122] & [0.131] & [0.141] \\
\hline \multirow[t]{2}{*}{ ITA } & $0.280^{* * *}$ & $0.268^{* * *}$ & $0.317^{* * *}$ & $0.390^{* * *}$ \\
\hline & {$[0.050]$} & {$[0.050]$} & {$[0.055]$} & [0.055] \\
\hline \multirow[t]{2}{*}{ SPA } & $-0.207^{* * *}$ & $-0.224^{* * *}$ & $-0.243^{* * *}$ & $-0.227^{* * *}$ \\
\hline & {$[0.061]$} & {$[0.060]$} & {$[0.068]$} & [0.068] \\
\hline \multirow[t]{2}{*}{ UK } & -0.065 & -0.164 & $-0.271^{* *}$ & $-0.232^{*}$ \\
\hline & [0.116] & [0.119] & [0.132] & {$[0.138]$} \\
\hline \multirow[t]{2}{*}{ Constant } & $-2.085^{* * *}$ & $-1.992^{* * *}$ & $-1.844^{* * *}$ & $-1.798^{* * *}$ \\
\hline & {$[0.220]$} & [0.219] & [0.229] & [0.240] \\
\hline Observations & 5526 & 5526 & 4946 & 4729 \\
\hline R-squared & 0.594 & 0.598 & 0.598 & 0.601 \\
\hline
\end{tabular}

OLS Estimations. The dependent variable is the log of the firm export value recorded in 2008 for exporters. All estimations include two-digit NACE dummies and are run on the weighted sample. The drop of the number of observations across columns is due to missing data for the firm level variables used in the regressions. Robust standard errors in brackets. ***, **, * significant at 1\%, 5\%, 10\%.

See Table A2 for the definition of variables. 
Table A13: Export intensive margin in China and India: OLS regression, only exporters with "family" variables

\begin{tabular}{|c|c|c|c|c|}
\hline \multirow{2}{*}{ VARIABLES } & (1) & \multirow{2}{*}{$\begin{array}{c}(2) \\
b\end{array}$} & \multirow{2}{*}{$\begin{array}{c}\text { (3) } \\
c\end{array}$} & \multirow{2}{*}{$\begin{array}{c}(4) \\
d\end{array}$} \\
\hline & $\mathrm{a}$ & & & \\
\hline \multirow[t]{2}{*}{ llp2 } & $0.826^{* * *}$ & $0.821^{* * *}$ & $0.826^{* * *}$ & $0.772^{* * *}$ \\
\hline & {$[0.077]$} & {$[0.075]$} & {$[0.080]$} & [0.078] \\
\hline \multirow[t]{2}{*}{ lsize } & $0.960^{* * *}$ & $0.937^{* * *}$ & $0.929^{* * *}$ & $0.928^{* * *}$ \\
\hline & [0.041] & {$[0.044]$} & [0.045] & [0.046] \\
\hline \multirow[t]{2}{*}{ grad_emp } & $0.019^{* * *}$ & $0.018^{* * *}$ & $0.016^{* * *}$ & $0.014^{* * *}$ \\
\hline & {$[0.004]$} & {$[0.004]$} & [0.004] & [0.004] \\
\hline \multirow[t]{2}{*}{ inno } & -0.060 & -0.055 & -0.027 & -0.094 \\
\hline & [0.125] & [0.126] & [0.133] & [0.137] \\
\hline \multirow[t]{2}{*}{ family_wide } & $-0.225^{*}$ & -0.153 & -0.252 & -0.232 \\
\hline & [0.132] & [0.137] & [0.159] & [0.162] \\
\hline \multirow[t]{2}{*}{ fam_exec } & & & 0.001 & 0.001 \\
\hline & & & {$[0.002]$} & {$[0.002]$} \\
\hline \multirow[t]{2}{*}{ group } & & 0.197 & 0.170 & 0.163 \\
\hline & & [0.135] & [0.144] & {$[0.140]$} \\
\hline \multirow[t]{2}{*}{ centralised } & & & & 0.131 \\
\hline & & & & [0.117] \\
\hline \multirow[t]{2}{*}{ forexp_exec } & & & & $0.296^{* * *}$ \\
\hline & & & & [0.113] \\
\hline \multirow[t]{2}{*}{ AUT } & $0.690^{* *}$ & $0.650^{* *}$ & $0.678^{* *}$ & $0.797^{* *}$ \\
\hline & [0.302] & [0.299] & {$[0.320]$} & [0.402] \\
\hline \multirow[t]{2}{*}{ FRA } & $-0.251^{*}$ & $-0.289^{* *}$ & $-0.313^{* *}$ & $-0.243^{*}$ \\
\hline & [0.135] & [0.138] & [0.139] & {$[0.143]$} \\
\hline \multirow[t]{2}{*}{ HUN } & 0.281 & 0.332 & 0.273 & 0.164 \\
\hline & [0.231] & [0.243] & [0.252] & [0.233] \\
\hline \multirow[t]{2}{*}{ ITA } & 0.176 & 0.164 & 0.159 & $0.232^{*}$ \\
\hline & {$[0.120]$} & {$[0.120]$} & {$[0.128]$} & [0.131] \\
\hline \multirow[t]{2}{*}{ SPA } & $-0.405^{* *}$ & $-0.421^{* *}$ & $-0.483^{* *}$ & $-0.419^{* *}$ \\
\hline & [0.171] & {$[0.170]$} & [0.198] & [0.198] \\
\hline \multirow[t]{2}{*}{ UK } & 0.052 & -0.018 & 0.045 & 0.021 \\
\hline & [0.197] & {$[0.200]$} & {$[0.228]$} & [0.239] \\
\hline \multirow[t]{2}{*}{ Constant } & $-3.060^{* * *}$ & $-3.046^{* * *}$ & $-2.788^{* * *}$ & $-2.625^{* * *}$ \\
\hline & [0.538] & [0.536] & [0.562] & [0.577] \\
\hline Observations & 1148 & 1148 & 1031 & 983 \\
\hline R-squared & 0.513 & 0.514 & 0.518 & 0.523 \\
\hline
\end{tabular}

OLS Estimations. The dependent variable is the $\log$ of the firm export value to China and India recorded in 2008 for exporters in those countries. All estimations include two-digit NACE dummies and are run on the weighted sample. The drop of the number of observations across columns is due to missing data for the firm level variables used in the regressions. Robust standard errors in brackets. ***, **, * significant at $1 \%, 5 \%, 10 \%$.

See Table A2 for the definition of variables. 